\title{
Maternal and Child Health Knowledge among Agrarian Mothers
}

\author{
Nasreen Banu* and K. Yashoda
}

AICRP-H.Sc (All India Coordinated Research Project-Home Science), PGRC, PJTSAU (Professor Jayashankar Telangana State Agricultural University), Rajendranagar, Hyderabad - 30, Telangana State, India

*Corresponding author

A B S T R A C T

\section{Keywords}

Maternal \& Child health, Intervention programme, Knowledge

Article Info

Accepted:

12 October 2018

Available Online:

10 November 2018
Present study was taken up to find out the Knowledge levels of the Agrarian mothers (with children below 2 years) in the adopted villages of Maheshwarammandal, RR district, Hyderabad with regard to Maternal \& Child health issues. 75 Agrarian mothers formed the sample for the present study. Checklist was developed to find out the Knowledge levels of Agrarian mothers. Based on the results, Knowledge based Intervention programmes were organized. Impact assessment showed significant improvement in the Knowledge levels of the sample, reflecting the effectiveness of the Intervention programme.

\section{Introduction}

Progress in maternal and child health depends on a country's capacity to achieve improvements in a range of areas both within and beyond the health sector. Health sector improvements include immunization, family planning, skilled birth attendance and the provision of antenatal and post-natal care. Improvements outside the health sector include reductions in the total fertility rate, economic development, good governance, the participation of women in politics and in the workforce, strong leadership, poverty reduction, female education and good environmental management. Women's autonomy and its relation to reproductive behaviour is a major area of concern, as it reduces maternal mortality and improves child health. A number of studies examined women's autonomy and its relationship with reproductive health outcomes and found that the status of women is an important determinant of maternal mortality and morbidity. Increase in women's autonomy will lead to mortality decline and improve health outcomes for women and their children.

A study in Uttar Pradesh in North India shows that women's autonomy is the major determinant of maternal health care utilization. The study shows that women with greater freedom of movement are more likely to receive antenatal care and to use delivery care. 
A study conducted by Kishor (2000), found women's autonomy to be an important explanatory factor in child survival. Another study in India has shown that women who score greater autonomy are more likely to use antenatal and delivery care for their last birth than women with lower autonomy. Better health care utilization rates have been reflected in south Indian women as they have greater autonomy as compared to north Indian.

Some of the studies have analyzed the causes of under- utilization of maternal health services and identified both quality and cost of care as important influencing factors. Maternal age and parity have also been found to be important determinants of health care use. Safilos-Roths (1982), found that income as a key indicator of women's status to examine fertility in rural Kenya.

Whereas Presser and Sen (2000), argue that women's socio-economic indicators such as education and employment are often not sensitive enough to capture the nuances of gender power relations and the ways in which they influence women's and men's reproductive behaviour. A study contends that assuming the low valuation of women as the root cause of lower utilization is a simplistic notion that fails to recognize the complex relations between women's position and other socio-economic factors and infrastructure that influence access to health care.

A study conducted by Rammu (1988), in India on urban, dual and single earning families found that the more resources the partner brought in to marriage, in terms of education, income and occupational status, the more decision-making power he/she possessed.

He also found that women who were gainfully employed exercised greater authority in all spheres of decision making compared to women engaged in domestic housework only.
Basu (2001) stated that female labour supply is both a matter for household decisionmaking and determinant of household balance of power.

Women's participation in gainful and visible employment improvises their bargaining position within the household and is associated with greater gender equality in the distribution of household resources than when women are employed in invisible activities.

\section{Operational definition}

\section{Knowledge}

Knowledge is a familiarity, awareness, or understanding of someone or something, such as facts, information, descriptions, or skills, which is acquired through experience or education by perceiving, discovering, or learning.

According to Webster's dictionary, knowledge is 'the fact or condition of knowing something with familiarity gained through experience or association'. In practice, though, there are many possible, equally plausible definitions of knowledge. A frequently used definition of knowledge is "the ideas or understandings which an entity possesses that are used to take effective action to achieve the entity's goal (s).

\section{Intervention}

An intervention is a combination of programme elements or strategies designed to produce behavior changes or improve health status among individuals or an entire population.

\section{Maternal health}

It refers to the health of women during pregnancy, childbirth and the postpartum period. 


\section{Child health}

It is a state of physical, mental, intellectual, social and emotional well-being and not merely the absence of disease or infirmity. Healthy children live in families, environments, and communities that provide them with the opportunity to reach their fullest developmental potential.

\section{Materials and Methods}

Sample was identified from the adopted villages (5) of Maheshwarammandal, RR District, Hyderabad, through field survey and focused group interviews with the help of the AWWs, ANMs, and Women Self-help Group leaders in the village.

\section{Criteria for sample selection}

Women who were married and living with their husband

Women who were married and having children

Women who were willing to be a part of the research project

\section{General objective}

Promoting Maternal and Child health Knowledge among Rural mothers

\section{Specific objectives}

To find out the demographic profiles of the Selected sample. To find out the Knowledge levels of the Selected sample with regard to Maternal \& Child health

\section{Research strategy adopted}

In order to achieve the above objectives, Knowledge based Intervention programmes
(20) were organized for the Rural mothers with children below 2 years, using the developed IEC material.

\section{Research tools details}

SES scale developed by Aggrawal, et al., (2005) was used to find out the SES of the Rural families. Scoring was given as per the norms provided in the manual.

It is a standardized scale, used to assess the family background information of the individuals, which includes parameters like educational and occupational status of parents, number of siblings, material possession, kind of locality, presence of farm animals, land holdings, number of earning members in the family etc.

The scale categorizes the sample on: Upper High; High; Upper middle; Lower middle; Poor and Very poor Socio Economic Status.

Maternal \& Child Health awareness checklist was developed by AICRP-CD, Hyd Unit (2017) to find out the Knowledge levels of Married women with regard to Maternal \& Child Health issues.

The Reliability Value of the checklist is: 0.85 . The checklist comprises of 3 dimensions:

\section{Pregnancy related statements}

It is the First dimension and has 48 statements. It measures the knowledge levels of the sample in the following 7 areas: Signs of Pregnancy (7 statements); Care during Pregnancy (9 statements); Factors affecting healthy pregnancy (6 statements); Health aspects of pregnancy (5 statements); Danger signs of pregnancy (11 statements); Complications that may arise during pregnancy (6 statements); Types of Delivery (4 statements). 
Maternal and child services and programmes

It is the Second dimension and has 33 statements. It measures the knowledge levels of the sample in the following 6 areas: Reproductive and child health programmes (5statements); Purpose of $\mathrm{R} \& \mathrm{CH}$ programmes (6 statements); Antenatal care services (5 statements); Purpose of Antenatal care services ( 8 statements); Post-natal care services (5 statements) Purpose of Postnatal care services (4 statements)

\section{General statements}

It is the Third dimension and has 13 statements. It measures the knowledge levels of the sample in the following 3 areas: Practices that jeopardize infant health, growth or survival (4statements); Care of the new born (3statements); Nutritional care of the child (6statements)

There are all together 94 statements (all 3 dimensions). Each statement is arranged on 3 point scale i.e. aware is marked as 3 ; aware but not sure 2; Not sure as 1 . The total scores were further grouped as Low, Average and high. Higher the score, higher is the level of Knowledge in that particular dimension.

\section{Results and Discussion}

\section{Demographic data on married women}

There were 961 married women from the selected clusters of adopted villages, Maheshwarammandal, RR district. Out of 961 married women, $41 \%$ (390) were having children below 2 years and 75 formed the sample for the present study.

Table 1 depicts the Age wise distribution of the sample (Rural mothers with children below 2 years). Out of the total sample 75, less than half of $(43 \%)$ were in the age range of $26-30 \mathrm{yrs} ; 40 \%$ were in the age group of $20-25$ yrs and the remaining $17 \%$ were in the age group of 31-35 yrs.

Table 2 depicts the Education wise distribution of the sample (Rural mothers with children below 2 years). Out of the total sample 75 , less than half of (40\%) completed Secondary school; 33\% completed Primary school; 11\% completed Inter; 9\% were illiterates and only $7 \%$ were pursuing their degree.

The table 3 depicts the Occupation wise distribution of the sample (Rural mothers with children below 2 years). Out of the total sample 75, thirty five percent of the sample were partially involved in agriculture; $33 \%$ were fully involved in agriculture; 23\%\% were housewives; and only $9 \%$ were running petit business.

The table 4 depicts the Socio Economic Status of the sample (Rural mothers with children below 2 years). Out of the total sample 75, more than half of $(64 \%)$ the sample were in lower middle income level; $21 \%$ were in poor economic status; $12 \%$ were in upper middle income level and only 3\% were in high income group.

The table 5 traces the pretest scores of married women with regard to Maternal Health \& Child care Knowledge / practices. The Self structured Checklist covers 3 dimensions.

With regard to Pregnancy dimension, out of 75 sample half $(51 \%)$ of the sample obtained Average scores; $29 \%$ obtained High scores and $20 \%$ obtained Low scores.

With regard to Maternal \& Child Services \& Programme dimension, out of 75 sample more than half (55\%) obtained Average scores; 28\%obtained High scores and 17\% obtained Low scores. 
Table.1 Age wise distribution of the Selected sample (N=75)

\begin{tabular}{|c|c|c|c|}
\hline $16-19$ yrs & $20-25$ yrs & $26-30 y r s$ & $31-35 y r s$ \\
\hline $\mathbf{N} \& \%$ & N \& \% & N \& \% & N \& \% \\
\hline & $30(40 \%)$ & $32(43 \%)$ & $13(17 \%)$ \\
\hline
\end{tabular}

Table.2 Education wise distribution of the Selected sample $(\mathrm{N}=75)$

\begin{tabular}{|c|c|c|c|c|}
\hline Illiterate & $\begin{array}{c}\text { Primary } \\
\text { school }\end{array}$ & $\begin{array}{c}\text { Secondary } \\
\text { school }\end{array}$ & Inter & $\begin{array}{c}\text { Degree } \\
\text { Continuing }\end{array}$ \\
\hline $\mathbf{N} \& \%$ & $\mathbf{N} \& \%$ & $\mathbf{N} \& \%$ & $\mathbf{N} \& \%$ & $\mathbf{N} \& \%$ \\
\hline $7(9 \%)$ & $25(33 \%)$ & $30(40 \%)$ & $8(11 \%)$ & $5(7 \%)$ \\
\hline
\end{tabular}

Table.3 Occupation wise distribution of the Selected sample $(\mathrm{N}=75)$

\begin{tabular}{|c|c|c|c|}
\hline $\begin{array}{c}\text { House wife } \\
\text { N \& \% }\end{array}$ & $\begin{array}{c}\text { Fully involved in } \\
\text { agriculture N \& \% }\end{array}$ & $\begin{array}{c}\text { Partially involved in } \\
\text { agriculture N \& \% }\end{array}$ & $\begin{array}{c}\text { Petit business } \\
\text { N \& \% }\end{array}$ \\
\hline $\mathbf{1 7}(\mathbf{2 3} \%)$ & $25(33 \%)$ & $26(35 \%)$ & $7(9 \%)$ \\
\hline
\end{tabular}

Table.4 Socio Economic Status of the sample $(\mathrm{N}=75)$

\begin{tabular}{|l|c|r|}
\hline $\begin{array}{l}\text { Socio economic status } \\
\text { classification }\end{array}$ & Score & $\begin{array}{r}\text { Married women with children } \\
\text { below 2 yrs (N=75) }\end{array}$ \\
\hline Upper High & $>76$ & ------ \\
\hline High & $61-75$ & $\mathbf{2 ( 3 \% )}$ \\
\hline Upper middle & $46-60$ & $\mathbf{9 ( 1 2 \% )}$ \\
\hline Lower middle & $31-45$ & $\mathbf{4 8 ( 6 4 \% )}$ \\
\hline Poor & $16-30$ & $\mathbf{1 6}(\mathbf{2 1 \%})$ \\
\hline Very poor & $<15$ & ----- \\
\hline
\end{tabular}

Table.5 Maternal and child health knowledge scores of rural mothers - pretest scores

\begin{tabular}{|l|l|l|l|l|}
\hline S.no & $\begin{array}{l}\text { Maternal \& child health } \\
\text { awareness dimensions }\end{array}$ & Category & Score & $\begin{array}{l}\text { Rural mothers with children } \\
\text { below 2 yrs 75 (No \& \%) }\end{array}$ \\
\hline A & Pregnancy & High & $97-144$ & $22(29 \%)$ \\
\hline & Average & $49-96$ & $38(51 \%)$ \\
\hline \multirow{2}{*}{$\begin{array}{l}\text { Maternal \& Child Services } \\
\text { \&programmes }\end{array}$} & Low & $<48$ & $15(20 \%)$ \\
\hline \multirow{2}{*}{ General } & High & $67-99$ & $21(28 \%)$ \\
\hline & Average & $34-66$ & $41(55 \%)$ \\
\hline & Low & $<33$ & $13(17 \%)$ \\
\hline & High & $27-39$ & $23(31 \%)$ \\
\hline & Average & $14-26$ & $38(51 \%)$ \\
\hline
\end{tabular}


Table.6 Maternal and child health knowledge scores of rural mothers (with children below 2 years) - Post assessment Scores: $\mathrm{N}=75$

\begin{tabular}{|l|l|l|l|r|}
\hline S.no & $\begin{array}{l}\text { Maternal \& child health } \\
\text { awareness dimensions }\end{array}$ & Category & Score & $\begin{array}{l}\text { Married women with children } \\
\text { below 2 yrs (No \& \%) }\end{array}$ \\
\hline A & Pregnancy & High & $97-144$ & $42(56 \%)$ \\
\cline { 3 - 5 } & Average & $49-96$ & $30(40 \%)$ \\
\hline B & $\begin{array}{l}\text { Maternal \& Child } \\
\text { Services \&programmes }\end{array}$ & High & $67-99$ & $3(4 \%)$ \\
& Average & $34-66$ & $41(55 \%)$ \\
\hline & Low & $<33$ & $27(36 \%)$ \\
\hline C & General & High & $27-39$ & $7(9 \%)$ \\
\hline & Average & $14-26$ & $42(56 \%)$ \\
\hline & Low & $<13$ & $30(40 \%)$ \\
\hline
\end{tabular}

Table.7 Maternal and child health awareness scores (pre \& post) of rural mothers with children < 2 yrs $(\mathrm{N}=75)$

\begin{tabular}{|c|c|c|c|c|c|c|c|c|c|}
\hline \multirow[t]{2}{*}{ Dimensions } & \multirow{2}{*}{$\begin{array}{c}\text { Sub- } \\
\text { Dimensions }\end{array}$} & \multicolumn{2}{|c|}{ Raw scores } & \multicolumn{2}{|c|}{ Mean } & \multicolumn{2}{|c|}{ SD } & \multirow{2}{*}{$\begin{array}{c}\text { Mean } \\
\text { differences } \\
\text { (P1-P) }\end{array}$} & \multirow{2}{*}{$\begin{array}{c}\mathrm{T} \\
\text { values }\end{array}$} \\
\hline & & (P) & (P1) & (P) & (P1) & (P) & (P1) & & \\
\hline \multirow{8}{*}{$\begin{array}{l}\text { A. Pregnancy } \\
\text { (48 statements) }\end{array}$} & A & 691 & 747 & 9.21 & 9.96 & 2.19 & 3.06 & 0.75 & $0.02 \mathrm{NS}$ \\
\hline & B & 923 & 1095 & 12.31 & 14.6 & 3.36 & 5.40 & 2.29 & $4.84 * *$ \\
\hline & C & 543 & 663 & 7.24 & 8.84 & 2.29 & 3.55 & 1.6 & $1.42 * *$ \\
\hline & D & 573 & 686 & 7.64 & 9.15 & 2.60 & 3.65 & 1.51 & $3.4 * *$ \\
\hline & $\mathbf{E}$ & 1395 & 1732 & 18.6 & 23.09 & 6.88 & 6.47 & 4.49 & $2.44 * *$ \\
\hline & $\mathbf{F}$ & 774 & 946 & 10.32 & 12.61 & 3.80 & 3.42 & 2.29 & $1.1^{* *}$ \\
\hline & G & 504 & 619 & 6.72 & 8.25 & 2.69 & 2.54 & 1.53 & $1.57 * *$ \\
\hline & Total & 5403 & 6488 & 72.04 & 86.51 & 21.01 & 24.92 & 14.47 & $2.41 * *$ \\
\hline \multirow{7}{*}{$\begin{array}{l}\text { B: Maternal \& } \\
\text { Child Services } \\
\text { and } \\
\text { programmes ( } 33 \\
\text { statements) }\end{array}$} & A & 507 & 569 & 6.76 & 7.59 & 2.32 & 3.09 & 0.83 & $0.01 \mathrm{NS}$ \\
\hline & B & 613 & 764 & 8.17 & 10.19 & 2.97 & 4.03 & 2.02 & $4.2 * *$ \\
\hline & C & 579 & 747 & 7.72 & 9.96 & 2.70 & 3.47 & 2.24 & $5.71 * *$ \\
\hline & D & 1026 & 1252 & 13.68 & 16.69 & 4.97 & 4.86 & 3.01 & $2.98^{* *}$ \\
\hline & $\mathbf{E}$ & 680 & 805 & 9.07 & 10.73 & 3.03 & 3.15 & 1.66 & $8.21 * *$ \\
\hline & $\mathbf{F}$ & 555 & 665 & 7.4 & 8.89 & 2.68 & 2.71 & 1.49 & $3.89^{* *}$ \\
\hline & Total & 3960 & 4802 & 52.8 & 64.03 & 16.02 & 18.19 & 11.23 & $3.66^{* *}$ \\
\hline \multirow{4}{*}{$\begin{array}{l}\text { C: General (13 } \\
\text { statements) }\end{array}$} & A & 450 & 575 & 6.0 & 7.67 & 1.81 & 2.0 & 1.67 & $6.41 * *$ \\
\hline & B & 374 & 458 & 4.99 & 6.11 & 1.88 & 1.65 & 1.12 & $1.37 * *$ \\
\hline & C & 827 & 965 & 11.03 & 12.87 & 4.03 & 3.47 & 1.84 & $1.96^{* *}$ \\
\hline & Total & 1651 & 1998 & 22.01 & 26.64 & 6.51 & 5.98 & 4.63 & $5.27 * *$ \\
\hline
\end{tabular}

Note: ** at $1 \%$ level of significance 


\section{Abbreviations}

\begin{tabular}{|l|l|l|}
\hline 1. Pregnancy & $\begin{array}{l}\text { 2.Maternal \& Child health } \\
\text { Services \& programmes }\end{array}$ & 3. General \\
\hline A: Signs of Pregnancy & $\begin{array}{l}\text { A: Reproductive \& child health } \\
\text { programmes }\end{array}$ & $\begin{array}{l}\text { A: Practices that jeopardize infant } \\
\text { health, growth or survival }\end{array}$ \\
\hline B: Care during Pregnancy & B: Purpose of R \& CH & B: Care of the new born \\
\hline C: Factors affecting healthy & C: Antenatal care services & C: Nutritional care of the child \\
\hline D: Health aspects of & D: Purpose of Antenatal care & \\
\hline E: Danger signs of pregnancy & E: Postnatal care services & \\
\hline F: Complications during & F: Purpose of Postnatal care & \\
\hline G: Types of Delivery & & \\
\hline
\end{tabular}

\section{Capacity building programmes}

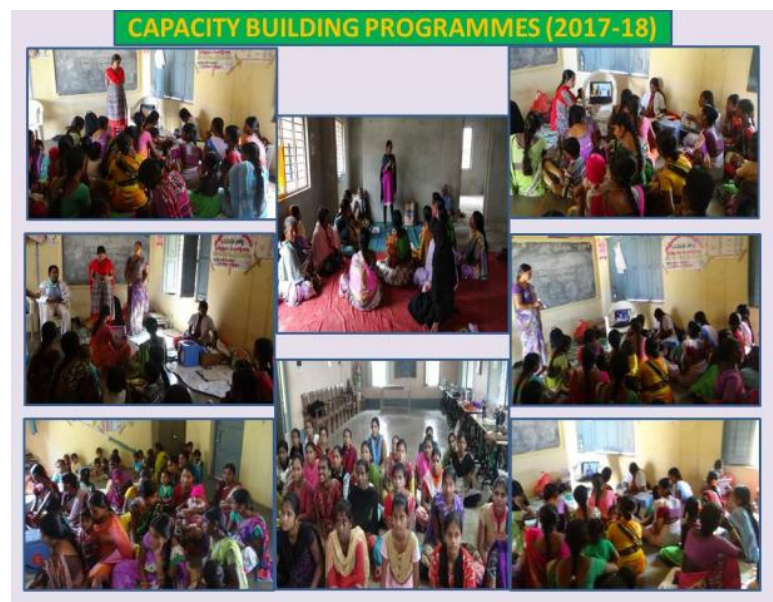

Reproductive Health knowledge scores of Married women (without children) - Dimension \& category wise

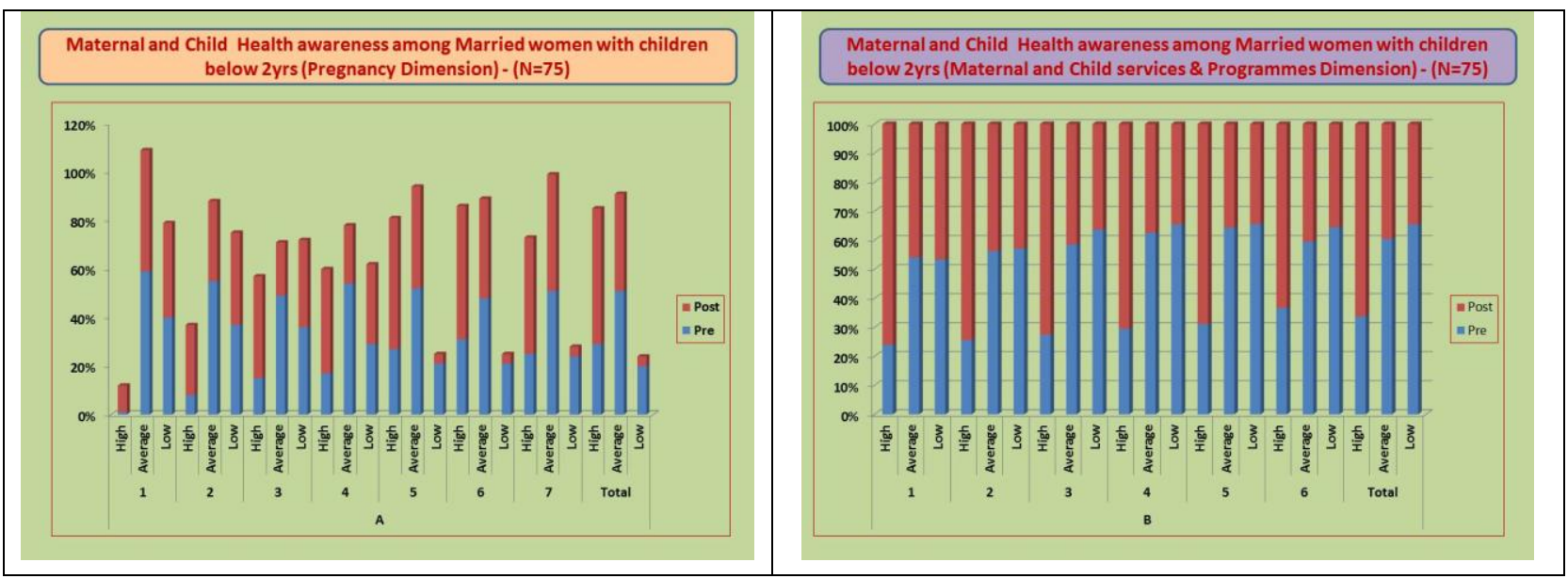



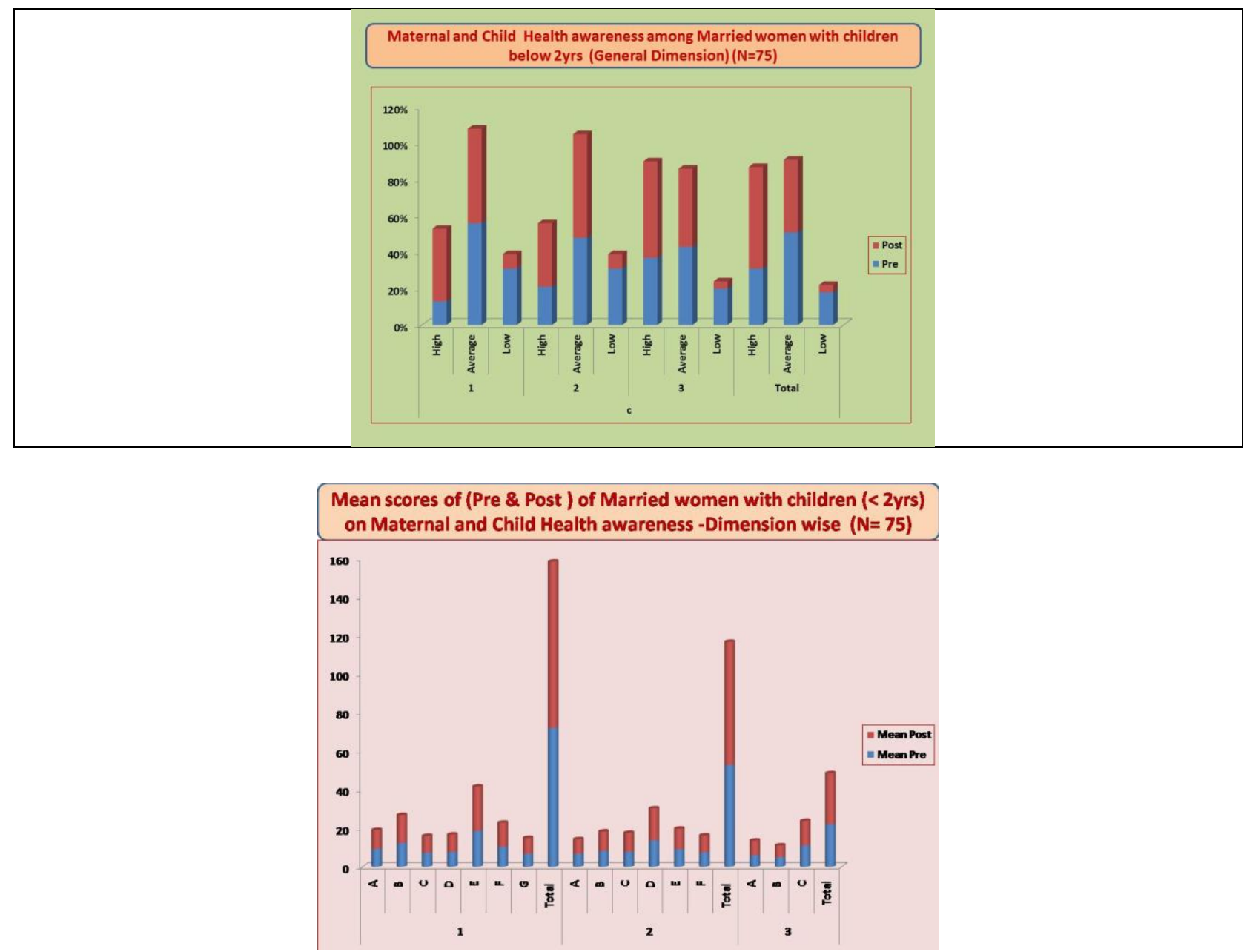

With regard to General dimension, out of 75 sample, half (51\%) obtained Average scores; $31 \%$ obtained High scores and $18 \%$ obtained Low scores.

Planning \& preparing educational material for conducting Awareness programmes on issues concerning Reproductive Health care among Rural mothers: Based on the bench mark issues and pre-assessment results, videos, brochures, leaflets, resource books and educational posters were planned / developed on selected thematic areas.

Educational posters mainly focused on: Balanced diet during Pregnancy; Birth control facts; Benefits of Breast feeding; Comprehensive nutrition; Condom use; Contraception choices; Healthy pregnancy;
HIV prevention; Transmission of AIDs; Transmission of STI/ RTI; Reproductive rights; Reproductive problems; Reproductive health; Antenatal care; Immunization schedule; Menstrual hygiene; Menstrual problems; Menstrual education; Neonatal health; Sanitary napkin; STI symptoms

A poster campaign is relatively easy to implement because of its low cost. The present cluster randomized controlled trial investigated the effectiveness of educational posters about Reproductive Health care in improving the knowledge level of Rural mothers. We adopted the cluster design because the intervention was conducted on the cluster level, instead of on the level of the individual Mother. Mothers in the same cluster read the same posters and may discuss 
these posters with each other, exerting influence in the process. Mothers in the same cluster may also have some special characteristics, for example, a particular interest in health information.

Conducting programmes on Maternal \& Child health for the selected sample: Knowledge based Capacity building programmes (20) were conducted for married women from the adopted villages on issues concerning Maternal \& Child health.

Some of the intervention strategies used for promoting Reproductive Health Knowledge among the sample was: group exercises, role plays, open ended stories, Brain storming, Group activities, Situation analysis, Case studies, Responding to real life situations and Group discussions etc.

\section{Interventions}

A comprehensive health education program was organized in 20 sessions for this group of rural mothers.

Each session was of two hours duration conducted on three consecutive days. The training methods included a didactic lecture followed by interactive sessions. The education was followed by an interactive session with the mothers to clarify doubts.

\section{Impact of knowledge based intervention}

The table 6 traces the pretest scores of married women with regard to Maternal Health \& Child care Knowledge / practices. The Self structured Checklist covers 3 dimensions.

With regard to Pregnancy dimension, out of 75 sample more than half $(56 \%)$ of the sample obtained High scores; $40 \%$ obtained Average scores and only $4 \%$ obtained Low scores.
With regard to Maternal \& Child Services \& Programmes dimension, out of 75 sample half (55\%) of the sample obtained High scores; $36 \%$ obtained Average scores and only 9\%obtained Low scores.

With regard to General dimension, out of 75 sample half (56\%) obtained High scores; $40 \%$ obtained Average scores and only $4 \%$ obtained Low scores.

The table 7 presents the Pre \& Posttest (Raw scores, Means, SD and T values) Scores of Married women (with children below 2 yrs) with regard to Sub-dimensions under Maternal Health and Child Care. The table shows the progressive increase in the total raw scores across pre-test to post-test, along with the increase in the mean differences, which shows the impact of intervention programme. $T$ values between the two means of pre-test and post-test was found to be highly significant, as the calculated values were found to be greater than the tabulated value. The results reflect the effectiveness of Intervention programmes on the Knowledge levels of Married women with reference to Reproductive Health.

Women who are in socio-economically advantageous position are much more likely to use MCH services. The most important result from this analysis on health-seeking behaviour is that several Socio-economic characteristics, particularly education of the women as well as economic status of household have strong positive association with health-care utilization. Women living in urban area are more likely to use maternal and child health care services particularly institutional delivery as well as antenatal care.

\section{References}

Basu, K. 2001. Gender and say: A model of household behavior with endogenously 
determined balance of power, Cornell University.

Kishor, S. 2000. Empowerment of women in Egypt and links to the survival and health of their infants. In: B. Presser \& G. Sen (Eds.), Women's empowerment and demographic processes. Oxford University Press, New York, 119-156.

Presser, H. and Sen, G. 2000. Women's Empowerment and Demographic Processes: Moving Beyond Cairo. Oxford University Press, UK.
Ramu, Gaddehosur N. 1988. Wife's economicstatus and marital power: A case of single and dual earner couples. Sociological Bulletin, 37: 49-69.

Safilios-Rothschild, C. 1982. Female power, autonomy and demographic change in the third world. In: R. Anker, M. Buvunic, and N. Youssek (Eds.), Women's roles and population trends in the third world, Croom Helm, London, 117-32.

\section{How to cite this article:}

Nasreen Banu and Yashoda, K. 2018. Maternal and Child Health Knowledge among Agrarian Mothers. Int.J.Curr.Microbiol.App.Sci. 7(11): 1367-1376.

doi: https://doi.org/10.20546/ijcmas.2018.711.159 